\title{
Utdanningsprogram i Dialektisk atferdsterapi (DBT) ved NSSF
}

Nasjonalt senter for selvmordsforskning og -forebygging (NSSF) har på oppdrag fra Helsedirektoratet (HDIR) tilbudt utdanning i den psykoterapeutiske behandlingsformen Dialektisk atferdsterapi (DBT) siden 2008. NSSF har med sitt sterke fagmiljø i DBT og etablerte samarbeid med terapiutvikler Marsha M. Linehan, hennes forskningsgruppe og andre fagmiljøer i utlandet, en naturlig posisjon som tilbyder av DBTutdanning i Norge. Utdanningen tilbys i nært samarbeid med Behavioral Tech (BTECH), som i en årrekke har utdannet DBT-terapeuter i USA og i Europa. Som del av dette samarbeidet har vi helt siden starten hatt lærere fra BTECH (personlig trent av Marsha M. Linehan) som bidragsytere i undervisningen på utdanningen. Dette er gjort for å sikre best mulig kvalitet på vårt tilbud, og for best mulig opplæring av våre egne DBT-lærere. Undervisningen er hittil hovedsakelig gitt på engelsk. Det arbeides aktivt for å tilby den på norsk.

\section{Nærmere om utdannings- tilbudet i DBT}

Behandlingsformen forutsetter at terapeuter samarbeider i team. Dette gjenspeiles også i opptakskriteriene til utdanningen, der klinikkene må søke inn team av behandlere. Teamet må bestå av minimum tre terapeuter hvorav en er teamleder. Erfaring viser oss at team med tre terapeuter er sårbart grunnet turnover/permisjoner etc., og det anbefales å søke inn team på minimum fire terapeuter. Tendensen de siste årene er at flere og flere klinikker søker inn team med opptil seks terapeuter.

Det at man tar utdanningen som team er essensielt for å kunne gi et godt behandlingstilbud, sikre bærekraft i tilbudet over tid og motvirke utbrenthet blant terapeuter. I teamet veileder man hverandre for å øke både kompetanse og motivasjon, og problemløser sammen i vanskelige saker. Undervisningen fordeles på to intensive undervisningsuker (del I og del II) med 7-9 måneder i mellom. I første undervisningsuke (del I) benyttes forelesninger, video og smågruppe-øvelser til grundig læring av DBT-teori og behandlingsstrategier. Undervisningen er basert på at deltakerne allerede i forkant av utdanningen har lest relevant litteratur. I perioden mellom del I og II skal teamene utforme, implementere og drive et DBT-behandlingstilbud på sin arbeidsplass. De får også en del andre hjemmeoppgaver som skal øke kompetansen i DBT. Som støtte i dette arbeidet får teamene månedlig telefonveiledning fra en ansvarlig DBT-lærer. I andre undervisningsuke (del II) presenterer teamene behandlingstilbudene sine og flere pasientkasus. De får veiledning og tips fra både

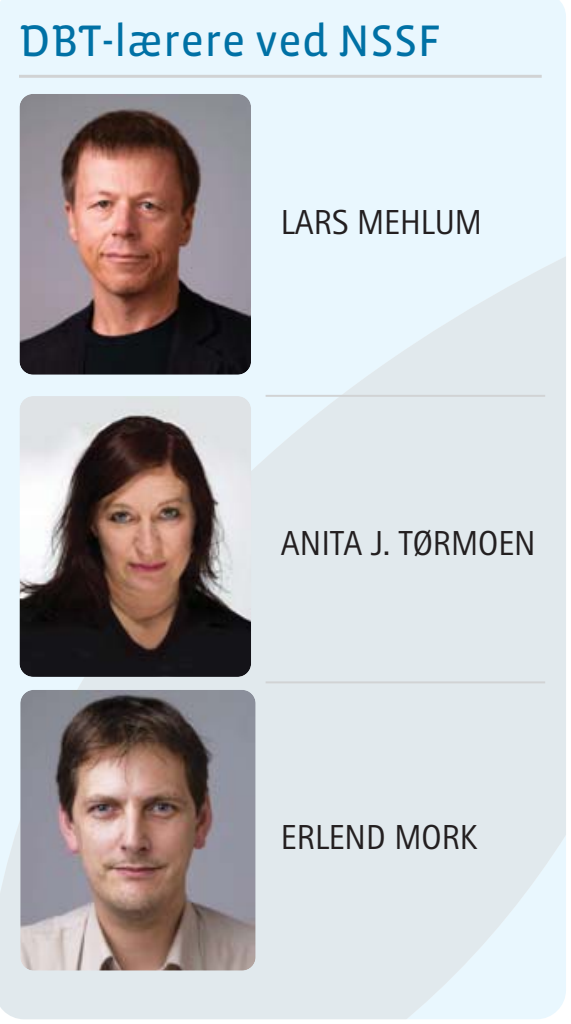

DBT-lærer, BTECH

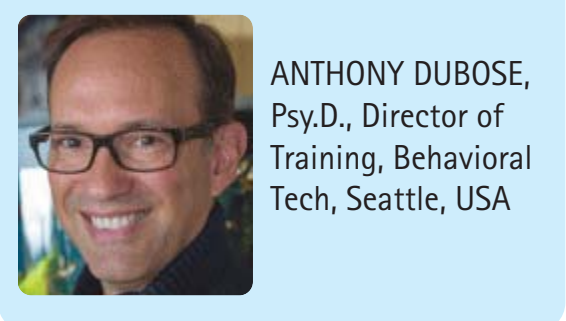

DBT-lærerne og hverandre om hvordan de kan videreutvikle både programmet og konkrete behandlingsløp.

Dersom etablerte DBT-team trenger å supplere teamet sitt med flere DBT-terapeuter kan de søke inn enkeltterapeuter (suppleringskandidater) til utdanningen. Suppleringskandidatutdanningen har et noe mindre omfang enn full terapeututdanning.

Det er økende interesse for utdanningen og til årets opptak var det nærmere $40 \%$ økning i antall søkere. 2014/2015-kullet startet utdanningen 27. oktober 2014 og består av 60 terapeuter. Det settes opp en suppleringskandidatutdanning til allerede tidlig i 2015 for å imøtekomme etterspørselen.

\section{Kurs og nasjonal konferanse i DBT}

Utdanningsprogrammet i DBT tilbyr også kurs av 1-3 dagers varighet. Dette er introduksjonskurs, videregående kurs for DBTterapeuter og klinikkinterne kurs der en av våre $\mathrm{DBT}$-lærere kan komme ut til klinikkene og holde en eller to dagers kurs. Utdanningsprogrammet arrangerer også hvert andre år en nasjonal konferanse i samarbeid med et lokalt DBT-miljø. I juni i år ble den 3. nasjonale konferansen i DBT arrangert i samarbeid med DBT-teamet BUP Lian i Trondheim. Konferansene er en viktig arena for DBT-terapeuter og er godt besøkt.

\section{Veiledning}

Alle DBT-team under utdanning får regelmessig telefonveiledning i 12 måneder fra oppstart på utdanningen. Veiledningen er meget viktig for utviklingen av robuste team og fungerer godt. Det tilbys også veiledning til aktive DBT-team der veiledningens innhold bestemmes av teamenes ønsker og behov. Våre norske DBT-lærere foretar all veiledning.

For nærmere informasjon om utdanningstilbudet, opptakskriterier, hvor i landet det er DBT-team, veiledning etc., se www.dbt.no 